Volume 13

Issue 1 Winter 2019

Article 6

January 2020

\title{
Third Generation Discrimination: An Empirical Analysis of Judicial Decision Making in Gender Discrimination Litigation
}

Catherine Ross Dunham

Christopher Leupold

Follow this and additional works at: https://via.library.depaul.edu/jsj

Part of the Civil Rights and Discrimination Commons, Law and Society Commons, Legislation Commons, Public Law and Legal Theory Commons, and the Social Welfare Law Commons

\section{Recommended Citation}

Catherine Ross Dunham \& Christopher Leupold, Third Generation Discrimination: An Empirical Analysis of Judicial Decision Making in Gender Discrimination Litigation, 13 DePaul J. for Soc. Just. (2020)

Available at: https://via.library.depaul.edu/jsj/vol13/iss1/6

This Article is brought to you for free and open access by the College of Law at Digital Commons@DePaul. It has been accepted for inclusion in DePaul Journal for Social Justice by an authorized editor of Digital Commons@DePaul. For more information, please contact digitalservices@depaul.edu. 


\title{
THIRD GENERATION DISCRIMINATION: AN EMPIRICAL ANALYSIS OF JUDICIAL DECISION MAKING IN GENDER DISCRIMINATION LITIGATION
}

\author{
Catherine Ross Dunham \\ Christopher Leupold
}

\section{INTRODUCTION}

In this progressive era of \#MeToo and other movements which highlight the reality of women's experiences in the workplace and other settings, the question arises as to why discrimination-based civil lawsuits are not more successful for female litigants. The courts have served as an important tool in reforming discriminatory workplace cultures by directly addressing and punishing overtly discriminatory workplace behavior such as blatant pregnancy and gender discrimination ${ }^{1}$ or grievous acts of sexual harassment. ${ }^{2}$ But the same courts have not been able to function as a safe haven for women who have their careers curtailed by implicit bias-based gender ${ }^{3}$ discrimination brought under Title VII. ${ }^{4}$ Gender discrimination lawsuits brought under a theory of bias-based discrimination have not offered reliable remedies for female litigants and have not positively impacted workplace culture in any meaningful way.

Bias-based gender discrimination theory involves structural discrimination-facially neutral

\footnotetext{
${ }^{*}$ Catherine Ross Dunham is a Professor of Law at the Elon University School of Law. She is an expert in the areas of civil procedure and class action litigation and has written and spoken on issues related to gender bias and pay equity. Dr. Christopher Leupold is an Associate Professor of Psychology at Elon University. The authors are especially grateful to Lisa Watson, J.D., M.L.S.. for research and other technical assistance.

${ }^{1}$ See 42 U.S.C. $§ 2000$ e-2(a) (2012); See generally Phillips v. Martin Marietta Corp., 400 U.S. 542, 544 (1971) (per curium); Dothard v. Rawlinson, 433 U.S. 321 (1977); Mieth v. Dothard, 418 F. Supp. 1169, 1171-74 (M.D. Ala. 1976).

${ }^{2}$ See Meritor Savings Bank, FSB v. Vinson, 477 U.S. 57, 57 (1986).

${ }^{3}$ The term gender as used in this Article is intended to refer to all people identifying as female and is not intended to limit the discussion of gender-based discrimination to persons who possess a female reproductive system and secondary sex characteristics.

${ }^{4}$ See, e.g., Wal-Mart Stores, Inc. v. Dukes, 564 U.S. 338, 344, 353 (2011); Pao v. Kleiner Perkins Caufield \& Byers, LLC, No. CGC-12-520719 (Cal. App. Dep’t Super. Ct. May 10, 2012).
} 
workplace policies that are applied to favor the male dominant group and consequently written and managed by a male-dominated upper hierarchy. ${ }^{5}$ Successful litigants in bias-based gender discrimination cases must convince the judicial decision-maker not only that the law of Title VII applies and the facts at issue constitute discrimination, but also that the workplace is mired in multi-layer structural discrimination flowing from an implicit bias against female employees. ${ }^{6}$ In order for federal courts to function fully as interpreters of Title VII, the judicial gatekeepers must engage their own biases and preconceptions when evaluating the subject workplace.

This article follows an earlier piece which theorized there is an additional layer of implicit bias-based discrimination which inhibits the success of plaintiffs in Title VII lawsuits. ${ }^{7}$ That article argued that lawsuits seeking relief under facts of implicit bias-based workplace discrimination are further inhibited by bias in the courts, specifically the implicit biases of the federal judges who monitor the progress of the plaintiff's case. ${ }^{8}$ This additional layer of implicit bias-based discrimination, Third Generation Discrimination, theorizes that a federal judge may be influenced by his or her own traits when evaluating gender discrimination cases which involve bias-based theories of gender discrimination. ${ }^{9}$

This article is based on the authors' study of Title VII cases in federal district courts over a ten-year period. The authors studied the judicial rulings on dispositive motions in Title VII cases and compared those outcomes to demographic information for the deciding judge, including race, gender, age and political affiliation. ${ }^{10}$ Part II summarizes the theories of Second and Third

\footnotetext{
${ }^{5}$ See generally Susan Sturm, Second Generation Employment Discrimination: A Structural Approach, 101 CoLuM. L. REV. 458 (2001).

${ }^{6}$ Id.

${ }^{7}$ See generally Catherine Dunham, Third Generation Discrimination: The Ripple Effects of Gender Bias in the Workplace, 51 AKRON L. REV. 55 (2017).

${ }^{8} \mathrm{Id}$. at $90-98$.

${ }^{9} \mathrm{Id}$. at 97 .

${ }^{10}$ The authors used the political party of the American President who first appointed the federal judge to the bench to
} 
Generation Discrimination, creating a framework for the research to follow. Part III describes and explains the relevant research by outlining the parameters of the sample, explaining the statistical method followed, and discussing the research results. Finally, Part IV analyzes the results of the authors' research and theorizes how the authors' findings can inform future discussions of gender discrimination.

\section{THE BACKGROUND: IMPLICIT BIAS-BASED GENDER DISCRIMINATION}

Second Generation Discrimination, also known as structural discrimination, is a theory of implicit bias-based gender discrimination available to female plaintiffs seeking relief for workplace discrimination under Title VII. ${ }^{11}$ Second Generation Discrimination theory argues implicit bias among supervisors or managers, those persons holding higher positions in the workplace hierarchy, leads to policies which favor the majority demographics, typically white and male, ${ }^{12}$ thereby excluding women from opportunities for advancement. ${ }^{13}$ The theory argues that gender-based discrimination flows from "ongoing patterns of interaction shaped by organizational culture." 14 The interactions, particularly those interactions between male employees, influence access, workplace conditions, and opportunities for advancement over time. ${ }^{15}$ If the group that controls access, conditions, and opportunities is all male, that group will begin to define "fit" and "success" in terms of those who fit and are successful in the workplace environment. ${ }^{16}$ The result

\footnotetext{
indicate the federal judge's political party affiliation. The sample was created based on available demographic information, thus actual political party affiliation or affinity at the time of the judicial decision in the sample was not determined. The term "political affiliation" as used here indicates only the political party of the Presidential appointer.

${ }^{11}$ See generally Sturm, supra note 5.

${ }^{12} \mathrm{Id}$.

${ }^{13}$ Id.; see also Dunham, supra note 7, at 77.

${ }^{14}$ Sturm, supra note 5 , at 470 .

${ }^{15} I d$. at 471 .

${ }^{16}$ Id. at 470-74; see also Benjamin Artz et al., Do Women Ask? 57 INDUS. Rel. 611 (2018) (concluding that women do ask for salary increases but receive less, which challenges the general hypothesis that women do not ask because they are worried about workplace relationships).
} 
is that traits deemed as masculine will take on a positive cast in the workplace, whereas traits deemed as more feminine will be unusual, misunderstood, and devalued in a male-dominated workplace environment. ${ }^{17}$ The bias-based culture works to affirm gender stereotypes, thus confirming the biases of male workers - whether conscious or unconscious - and leading to a discriminatory workplace environment for women who attempt to join or advance. ${ }^{18}$

Second Generation Discrimination recognizes three co-dependent constructs which work together to create a culture of workplace discrimination. ${ }^{19}$ First, the workplace utilizes a faciallyneutral policy, in which the bias-based discrimination violates a "norm of functional, as opposed to formal, equality of treatment" by applying a facially-neutral practice or policy to a group of similarly situated employees. ${ }^{20}$ The second construct contemplates the effect of formal policies on the dominant group, evaluating whether a workplace policy violates a norm of equal access. ${ }^{21}$ The third construct contemplates stereotype and bias, analyzing the effect of using sex stereotyping to exclude. $^{22}$ These three constructs create a self-perpetuating cycle of discriminatory policies and actions. $^{23}$

\footnotetext{
${ }^{17}$ See Justin Levinson \& Danielle Young, Implicit Gender Bias in the Legal Profession: An Empirical Study, 18 DUKE J. GENDER L. \& POL'Y 1, 11-14 (2010) (examining gender stereotypes in the legal profession) (citing Joan C. Williams, The Social Psychology of Stereotyping: Using Social Science to Litigate Gender Discrimination Cases and Defang the “Cluelessness" Defense, 7 EMP. RTS. \& EMP. POL’Y J. 401, 439 (2003)).

${ }^{18}$ Sturm, supra note 5, at 471-75.

${ }^{19} \mathrm{Id}$. at $473-74$.

${ }^{20} \mathrm{Id}$. (the focus is on a group of employees that is predominantly female, such that female employees are disproportionately impacted by the practice or policy); see also Dunham, supra note 7, at 79.

${ }^{21}$ Sturm, supra note 5, at 473-74 ("Second generation bias could also violate a norm of equal access, which defines discrimination to include employment decisions that are formally fair but functionally biased in favor of the dominant group by using criteria that advantage one group over another for arbitrary reasons, meaning reasons that do not advance the articulated goals of the employment decision.").

${ }^{22} \mathrm{Id}$. at 474 ("A third possibility is that these subtle, exclusionary practices violate an antisubordination principle, which itself is a plural normative category that could include stereotyping, gender policing, undermining women's competence, or maintaining gender or racial hierarchy.").

${ }^{23}$ See Dunham, supra note 7, at 82; see, e.g., Id. at 81 ("If male managers witnessed the exclusion of women as less suited to management, through the relocation policy or otherwise, those male managers were then validated in their beliefs that men were better candidates for promotion. The corporate culture evolved from there into a culture with male-dominated management — a single-sex environment that offered no check on bias."); see, e.g., Wal-Mart
} 
The third construct doubles back to the first, and a continuum of unchecked bias develops: facially-neutral formal policies develop, the formal policies are applied disproportionately based on the gender demographics of the subject group of employees, the female employees have restricted access under the formal policies, the male employees access management as a favored dominant group, and the male-dominated manager group is allowed to employ discretion based on sex stereotypes unchecked by a formal corporate practice. ${ }^{24}$ This interplay among the three constructs creates a continuum wherein the result is a continuous culture of bias and discrimination. ${ }^{25}$

\section{Figure 1.1: The Second Generation Discrimination Continuum ${ }^{26}$}

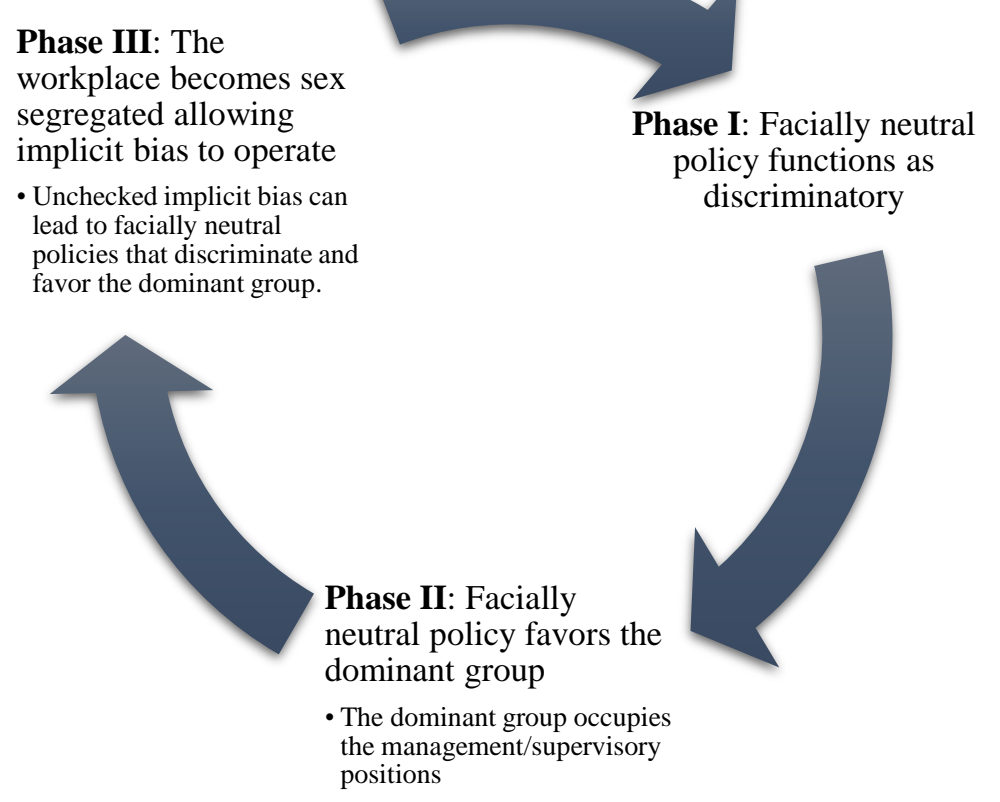

Stores, Inc. v. Dukes, 564 U.S. 338 (2011).

${ }^{24}$ Dunham, supra note 7 , at 82 .

${ }^{25} I d$.

${ }^{26} \mathrm{Id}$; see also Sturm, supra note 5, at 473-74. 
Although overt gender discrimination has been successfully challenged, the implicit biasbased species of gender discrimination understood as Second Generation Discrimination has endured despite legal challenges. ${ }^{27}$ One theory for why Second Generation cases have not been more successful is the complexity of the claims themselves. ${ }^{28}$ In stating a Second Generation Discrimination claim, the implicit bias-based nature of the claim must be understood by the trial judge first, then the jury, and then, possibly, appellate courts. ${ }^{29}$ The necessary understanding must be more than intellectual, as the very nature of the discrimination claim rests in human behavior that operates at an unconscious level. ${ }^{30}$

The Second Generation Discrimination Continuum depicts a cycle of bias-based behaviors that self-perpetuates and creates environments that offer few opportunities for change. ${ }^{31}$ A similar cycle has evolved in the court's review of implicit bias-based gender discrimination cases. ${ }^{32}$ The federal judiciary is predominantly male and over 50 , meaning that

\footnotetext{
${ }^{27}$ See Wal-Mart Stores, Inc. v. Dukes, 564 U.S. 338 (2011); see also Price Waterhouse v. Hopkins, 490 U.S. 228 (1989); Puffer v. Allstate, 255 F.R.D 450 (N.D. Ill. 2009); Wolf v. MWH Constructors, 34 F. Supp. 3d 1213 (M.D. Fla. 2014); Culleton v. Honeywell Int'l, 257 F. Supp. 3d 333(E.D.N.Y. 2017); Chadwick v. Wellpoint, 550 F. Supp. 2d 140 (D. Me. 2008); Kerman v. Fin. Indus. Regulatory Auth. (FINRA), 814 F. Supp. 2d 355 (S.D.N.Y. 2011); Fanelli v. New York, 200 F. Supp. 3d 363 (E.D.N.Y. 2016); Talavera v. Fore, 684 F. Supp. 2d 118 (D.D.C. 2009); Weightman v. Bank of New York Mellon Corp., 772 F. Supp. 2d 693 (W.D. Pa. 2011); Day v. Sears Holding Corp., 930 F. Supp. 2d 1146 (C.D. Cal. 2013); Lewis v. Heartland Inns of America, LLC, 585 F. Supp. 2d 1046 (S.D. Iowa 2008); Coons v. Walsh Constr., 836 F. Supp. 2 d 690 (N.D. Ill. 2011); Conlay v. Baylor Coll. of Med., 688 F. Supp. 2d 586 (S.D. Tex. 2010); Vuona v. Merrill Lynch \& Co., 919 F. Supp. 2d 359 (S.D.N.Y. 2013); but see HellmannBlumberg v. Univ. of the Pacific, No. 2:12-cv-00286 TLN DAD, 2014 WL 1025111 (E.D. Cal. March 17, 2014); Lewis v. CNA Nat'l Warranty Corp., 63 F. Supp. 3d 959 (D. Minn. 2014); Geraty v. Village of Antioch, 941 F. Supp. 2d 918 (N.D. Ill. 2013); Tse v. UBS Fin. Servs., 568 F. Supp. 2d 274 (S.D.N.Y. 2008); Arnold v. Reliant Bank, 932 F. Supp. 2d 840 (M.D. Tenn. 2013); Clayton v. Vanguard Car Rental U.S.A., Inc., 761 F. Supp. 2d 1210 (D.N.M. 2010); Shervin v. Partners Healthcare Sys., Inc., 2 F. Supp. 3d 50 (D. Mass. 2014).

${ }^{28}$ See generally Sturm, supra note 5; see also supra Continuum, Figure 1.1 p. 5.

${ }^{29}$ See Dunham, supra note 7, at 92-93.

${ }^{30}$ See Jerry Kang et al., Implicit Bias in the Courtroom, 59 UCLA L. REV. 1124, 1160-61 (2012) (citing Vincent Y. Yzerbyt et al., Social Judgeability: The Impact of Meta-Informational Cues on the Use of Stereotypes, 66 J. PERSONALITY \& SOC. PSYCHOL. 48 (1994) which developed the theory of "social judgeability"); see also Rita Handrick, When it Comes to Gender Bias, Judges Have it Too, KeEne Trial Consulting: The Jury Room (July 5, 2018), http://keenetrial.com/blog/2018/07/05/when-it-comes-to-gender-bias-judges-have-it-too/.

${ }^{31}$ See supra Figure 1.1 p. 7.

${ }^{32}$ See Dunham, supra note 7, at 96-98.
} 
those presiding over motions to dismiss are less likely to possess the experiences and information that is necessary to facilitate a full understanding of Second Generation Discrimination. ${ }^{33}$ The dynamics of judging and the demographics of the judiciary create another obstacle to reliefThird Generation Discrimination. ${ }^{34}$

\section{The Third Generation Discrimination Continuum (Figure 1.2)}

Phase III: The procedural rule's interpretation protects the dominant group in future Title VII litigation.

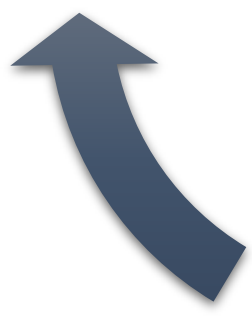

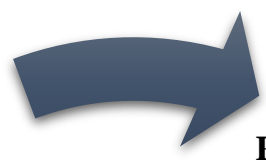

Phase I:The Title VII litigation requires judical action under a procedural rule.

Phase II:The procedural rule is interpreted to favor

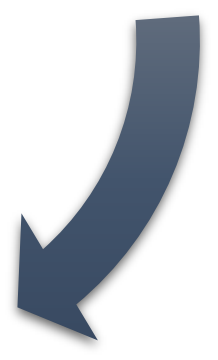
the Title VII defendant.

Like the theory of Second Generation Discrimination, Third Generation Discrimination also operates on a continuum that can proceed without interruption if certain factors are present. ${ }^{35}$ Consider a hypothetical case where the gravamen of the female plaintiff's claim is that she was

\footnotetext{
${ }^{33}$ Demography of Article III Judges, 1789-2017, FED. JUDICIAL CTR., https://www.fjc.gov/history/exhibits/graphsand-maps/age-and-experience-judges (last visited Feb. 25, 2019); see also Women in the Federal Judiciary: Still a Long Way to Go, NAT'L WOMEN's LAW CTR.: FACT SHEET (Oct. 2016), https://nwlc.org/resources/women-federaljudiciary-still-long-way-go/ (noting that there have only been four women justices on the U.S. Supreme Court with three currently sitting on the Court; 60 of 167 (36\%) of circuit court judges are women; and 33\% of United States District Court judges are women).

${ }^{34}$ See Dunham, supra note 7, at 96. See also EnHANCING Justice: Reducing Bias 97 (Sarah E. Redfield ed. 2018).

${ }^{35}$ See Dunham, supra note 7, at 96-98.
} 
discriminated against by her employer through the use of discretionary pay and promotion policies administered by male managers. ${ }^{36}$ The theory of the case is predicated on Second Generation Discrimination under Title VII. ${ }^{37}$ Assume the defendant files a motion to dismiss the plaintiff's complaint per Rule 12(b)(6), arguing the plaintiff has failed to state a claim that is plausible on its face, triggering Phase I in the Third Generation Continuum. ${ }^{38}$ Rule 12(b)(6) is a facially-neutral rule of civil procedure designed to dismiss implausible claims, eliminating the time and expense of further pleading or discovery. ${ }^{39}$ Next, assume the trial judge lacks personal experience with gender-based discrimination either through his experience as an attorney or his experience as a judge. ${ }^{40}$ In the absence of individualized information about this case or these parties, the judge may default to categorical information ${ }^{41}$ when judging the defendant's claim for relief and dismiss

\footnotetext{
${ }^{36}$ See generally Wal-Mart Stores, Inc. v. Dukes, 564 U.S. 338 (2011).

${ }^{37}$ Id.; see also Roger W. Reinsch \& Sonia Goltz, You Can't Get There from Here: Implications of the Wal-Mart v. Dukes Decision for Addressing Second Generation Discrimination, 9 Nw. J. L. \& Soc. POL’Y 264, 280 (2014) (“Dukes fundamentally changed how courts address second-generation discrimination ....”).

${ }^{38}$ FED. R. CIV. P. 12(b)(6); see also supra Figure 1.2 p. 7.

${ }^{39}$ FED. R. CIV. P. 12(b)(6); Ashcroft v. Iqbal, 556 U.S. 662, 678-80 (2009); Bell Atlantic Corp. v. Twombly, 550 U.S. 544, 555 (2007) (cases holding that to survive a motion to dismiss at the pleading stage, the complaint must meet a plausibility standard).

${ }^{40}$ See generally JOAN C. Williams ET. AL, ABA COMM'N ON WOMEN In THE PROFESSION, You CAN'T ChANGE What You CAN'T SEe: InTERRUPting RACIAL \& Gender Bias IN THE LEgAL Profession (2018), https://www.americanbar.org/content/dam/aba/administrative/women/Updated\%20Bias\%20Interrupters.pdf.

${ }^{41}$ See Jerry Kang et al., Implicit Bias in the Courtroom, 59 UCLA L. REV. 1124, 1132 (2012) ("[E]xplicit biases are attitudes and stereotypes that are consciously accessible through introspection and endorsed as appropriate. If no social norm against these biases exists within a given context, a person will freely broadcast them to others. But if such a norm exists, then explicit biases can be concealed to manage the impressions that others have of us. By contrast, implicit biases are attitudes and stereotypes that are not consciously accessible through introspection."); see also Justin Levinson \& Danielle Young, Implicit Gender Bias in the Legal Profession: An Empirical Study, 18 DUKE J. GENDER L. \& POL'Y 1, 6 (2010) (citing Antony Page, Batson's Blind-Spot: Unconscious Stereotyping and the Peremptory Challenge, 85 B.U. L. REV. 155, 203-04 (2005)) ("In the context of gender stereotypes, children are likely to learn at an early age that men are 'competent, rational, assertive, independent, objective, and self-confident,' and women are 'emotional, submissive, dependent, tactful, and gentle."'
} 
the plaintiff's claim as not plausible. ${ }^{42}$ If so, the facially-neutral rule, Rule 12(b)(6), has been interpreted to favor the employer-defendant, illustrating Phase II of the Continuum. ${ }^{43}$

Finally, assume the plaintiff appeals the trial judge's ruling dismissing her case. The plaintiff-appellant is now asking the appellate judiciary to assess the lower court's action, which requires the appellate court to assess de novo the plausibility of the claim. ${ }^{44}$ If the appellate court affirms the lower court, this new interpretation of Rule 12(b)(6) can perpetuate a general misunderstanding of the Second Generation Discrimination claim and weaken the availability of the theory for other litigants. ${ }^{45}$ The cycle will then repeat, as the first case becomes precedent for the next, diminishing the viability of bias-based gender discrimination litigation and validating the suspect employment practice. ${ }^{46}$

To test the theory of Third Generation Discrimination, which is predicated on the idea that judicial traits and experiences impact the litigant's success in Title VII litigation, the authors studied Title VII cases brought in federal district courts for a ten year period. ${ }^{47}$ The study was designed to test the relationships between case outcomes at the dispositive motion stage and certain

\footnotetext{
${ }^{42}$ See Kang et al., supra note 41, at 1146; see also Vincent Y. Yzerbyt et al., Social Judgeability: The Impact of Meta-Informational Cues on the Use of Stereotypes, 66 J. PERSONALITY \& SOC. PSYCHOL. 48, 49 (1994). In discussing a study on social judgeability, the authors note that because participants in the study had received no individuating information about the study subjects, the study participants tended to judge the subjects in accordance with their schemas, or categorical information, about the subjects, basing their judgments on general, categorical information about comedians and archivists.

${ }^{43}$ See supra Figure 1.2 p. 7.

${ }^{44}$ See Bell Atlantic Corp. v. Twombly, 550 U.S. 544, 555 (2007) (holding that the appellate court reviews de novo the trial court's ruling on a motion to dismiss under Rule 12(b)(6)); See also Women in the Federal Judiciary: Still a Long Way to Go, NAT'L WOMEN's LAW CTR.: FACT SHEET (Oct. 2016), https://nwlc.org/resources/women-federaljudiciary-still-long-way-go/ (noting that there have only been four women justices on the U.S. Supreme Court with three currently sitting on the Court; 60 of 167 (36\%) of circuit court judges are women; and 33\% of United States District Court judges are women).

${ }^{45}$ See Fed. R. CIV. P. 12(b)(6); see also Ashcroft v. Iqbal, 556 U.S. 662, 678-80 (2009) and Bell Atlantic Corp. v. Twombly, 550 U.S. 544, 555 (2007).

${ }^{46}$ See supra Figure 1.2 p. 7.

${ }^{47}$ For readers who are interested in obtaining the complete data file, please contact the first author.
} 
demographic traits of the deciding judge. ${ }^{48}$ Specifically, the authors studied whether a judge's gender, race, age, and political affiliation impacts a judge's rulings on dispositive motions in Title VII gender discrimination claims. ${ }^{49}$ As is discussed below, the authors determined that age was the most influential demographic trait in determining the success of a female plaintiff's gender discrimination claim..$^{50}$

\section{THE RESEARCH: SAMPLE, METHOD, AND RESULTS}

The research sample of 160 cases was derived from a comprehensive research pool which included 1014 federal cases decided between January 1, 2008 through April 30, 2018. The research focused on claims filed under Title VII based on allegations of gender discrimination in the workplace. ${ }^{51}$ The full research pool was narrowed to focus on cases wherein a single judge made a dispositive ruling, such as a ruling on a motion to dismiss under Rule 12(b)(6) or a motion for summary judgment, and included a written opinion addressing the strengths and weaknesses of the Title VII gender discrimination claim. ${ }^{52}$ The sample includes cases premised on allegations of overt discrimination, sexual harassment, and implicit bias-based discrimination and includes cases wherein the Federal Title VII claims are joined with other state and federal claims of discrimination. Cases included in the sample were coded as either favoring the plaintiff(s) or favoring the defendant(s). ${ }^{53}$ Data was also gathered on the age, gender, race, and political

\footnotetext{
${ }^{48}$ See infra pp. 11.

${ }^{49} \mathrm{Id}$.

${ }^{50}$ See infra pp. 25-28.

${ }^{51}$ See 42 U.S.C. § 2000e-2(a) (2012) ("It shall be an unlawful employment practice for an employer-(1) to fail or refuse to hire or to discharge any individual, or otherwise to discriminate against any individual with respect to his compensation, terms, conditions, or privileges of employment, because of such individual's race, color, religion, sex, or national origin; or (2) to limit, segregate, or classify his employees or applicants for employment in any way which would deprive or tend to deprive any individual of employment opportunities or otherwise adversely affect his status as an employee, because of such individual's race, color, religion, sex, or national origin.") (emphasis added).

${ }^{52}$ See FED. R. CIV. P. 12(b)(6) and FED. R. CIV. P. 56.

${ }^{53}$ See infra p. 14.
} 
affiliation of the judge making the dispositive ruling for each case included in the sample. ${ }^{54}$

\section{A. THE RESEARCH SAMPLE}

Searches for case law sought federal cases from January 1, 2008 through April 1, 2018, including case law from all federal district courts and courts of appeal for all federal circuits. ${ }^{55}$ Searches focused on the terms "gender discrimination" and "sex discrimination" 56 combined with searches for cases filed under Title VII and related federal law addressing sex discrimination in the workplace. ${ }^{57}$ Searches also included the terms "bias," "implicit bias" based gender discrimination claims not arising in the workplace context. ${ }^{59}$

In determining which cases from those surveyed would be included in the research sample, the authors employed the following parameters in narrowing the case law to those cases most relevant to a study of the theory of Third Generation Discrimination. ${ }^{60}$

- The case law included in the sample includes claims by female plaintiffs asserting discrimination based on sex as prohibited by Title VII. ${ }^{61}$ This description includes cases for: disparate treatment ${ }^{62}$ and disparate impact ${ }^{63}$ discrimination; sexual harassment; quid

\footnotetext{
${ }^{54}$ See supra note 10; see also infra p. 20.

55 The authors included federal appeals court cases in the research inquiries but did not include appellate cases in the sample as the appellate opinions had multiple authors or were per curium, thus not offering a reasonable basis on which to compare judicial demographics to outcomes.

56 The actual search terms used were: "SY((sex! or gender $/ 5$ discrimination)) \% "title ix" then narrowed to aft 01/01/2008, court, Labor \& Employment and the term "bias". SY = synopsis; \% Title IX = do not retrieve cases that contain the word "Title IX," "implicit bias" then narrowed to aft 01/01/2008, court, Labor \& Employment and the term gender or sex! w/5 discrimination," and "implicit bias" then narrowed to aft 01/01/2008, court, Labor \& Employment and the term gender or sex! w/5 discrimination."

5742 U.S.C. $\$ 2000 \mathrm{e}-2$ (a) (2012).

${ }^{58}$ See Dunham, supra note 7, at 60.

59 The research sample intentionally excluded cases filed under 20 U.S.C. § 1681(a) (Title IX).

${ }^{60}$ See generally Dunham, supra note 7.

${ }^{61}$ See Price Waterhouse v. Hopkins, 490 U.S. 228, 239 (1989) (the Court states that it takes Title VII's prohibition against discrimination based on sex "to mean that gender must be irrelevant to employment decisions."). ${ }^{62} I d$.

${ }^{63}$ Id. ("Indeed, Title VII even forbids employers to make gender an indirect stumbling block to employment opportunities. An employer may not, we have held, condition employment opportunities on the satisfaction of facially neutral tests or qualifications that have a disproportionate, adverse impact on members of protected groups when those tests or qualifications are not required for performance of the job.")
} 
pro quo sexual harassment; and hostile environment. ${ }^{64}$ The sample also includes gender discrimination cases grounded in pregnancy discrimination. ${ }^{65}$

- The sample includes cases of gender discrimination wherein the plaintiff's claims are combined with allegations of race, age or other actionable discrimination. ${ }^{66}$ In reviewing those cases, the analysis focused on the gender discrimination claims. Cases where the gender discrimination claims could not be separated from other discrimination claims were excluded from the sample.

- The sample does not include gender discrimination cases where the allegations of discrimination focused on allegations of discrimination based on sexual orientation, including allegations of discrimination based on transgender status. ${ }^{67}$

- The sample does not include gender discrimination cases where the lead plaintiff is a heterosexual male arguing he was discriminated against based on his gender. ${ }^{68}$

- The sample does not include gender discrimination cases wherein the Title VII sex discrimination claims are not the factual gravamen of the discrimination claim. ${ }^{69}$

\footnotetext{
${ }^{64}$ See, e.g., Perry v. Autozoners, LLC, 954 F. Supp. 2d 599 (W.D. Ky. 2013). To state a claim for quid pro quo sexual harassment "... a plaintiff must assert and prove (1) that the employee was a member of a protected class; (2) that the employee was subjected to unwelcomed sexual harassment in the form of sexual advances or requests for sexual favors; (3) that the harassment complained of was based on sex; (4) that the employee's submission to the unwelcomed advances was an express or implied condition for receiving job benefits or that the employee's refusal to submit to a supervisor's sexual demands resulted in a tangible job detriment; and (5) the existence of respondeat superior liability. To state a claim for hostile work environment sexual harassment, a plaintiff must show that "(1) she was a member of a protected class; (2) she was subjected to unwelcome sexual harassment; (3) the harassment was based on sex; (4) the harassment created a hostile work environment; and (5) there is a basis for holding the employer liable."

${ }^{65}$ See, e.g., Antonich v. U.S. Bank Nat'l Ass'n, No. 14-CV-710, 2015 WL 4771551 (D. Minn. Aug. 13, 2015).

${ }^{66}$ See, e.g., Ruffin v. Lockheed Martin, 126 F. Supp. 3d 521 (D. Md. 2015) (combined claims for race and gender discrimination under Title VII and claims under the Americans with Disabilities Act of 1990, 42 U.S.C.A. § 12101 et seq.)

${ }^{67}$ See, e.g., Brandon v. Sage Corp., 61 F. Supp. 3d 632 (W.D. Tex. 2014) (although transgender persons are not a per se protected class under Title VII, transgender persons can prevail on discrimination claims by showing discrimination occurred because the plaintiff failed to conform to gender stereotypes). The authors did not include discrimination cases brought by transgender plaintiffs in the sample because the bias issues in transgender discrimination cases raised potentially different issues which could alter the credibility of the statistical method. ${ }^{68}$ As the focus of the research is judicial bias against claims by women in the workplace, claims by men raised other issues of judicial bias, for example, bias against men who complain of unfair treatment by women or other men, which are outside the purview of this research.

${ }^{69}$ See, e.g., Catcove Corp. v. Heaney, 685 F. Supp. 2d 328 (E.D.N.Y. 2010) (allegations of discrimination and retaliation by female land developer who alleged she was prevented from completing her shopping center development and forced to sell property; her claims focused principally on equal protection and First Amendment arguments).
} 
- The sample includes only cases brought in federal court under Title VII, thus under federal question subject matter jurisdiction. ${ }^{70}$ The sample includes cases that combine Title VII claims with similar state law provisions. ${ }^{71}$

- The sample includes cases where the legal and factual analysis is based on a dispositive motion, ${ }^{72}$ thus requiring the court to fully analyze the pleadings and/or facts and consider whether the case should proceed in litigation. ${ }^{73}$

- The sample does not include cases wherein the court is examining damages awards following a trial, motions for a new trial, or any other post-verdict review.

In addition to using the above-noted parameters to narrow the full research results to a workable study sample, the authors also employed a coding process to determine whether cases in the sample favored the plaintiff or the defendant. The goal of the coding was to allow for comparison between the outcome of the case and the demographics of the presiding judge, creating a set of outcome demographics for purposes of the statistical method. ${ }^{74}$ As the cases in the sample represent complex litigation involving multiple issues of fact and law, including state and federal law, the coding was based on a determination of whether any of the plaintiffs' gender discrimination claims were allowed to proceed to the next step of litigation. ${ }^{75}$ If any gender discrimination claim was allowed to proceed, the case was coded as "favoring plaintiff." If the

\footnotetext{
7028 U.S.C. $\S 1331$ (2012).

${ }^{71}$ See, e.g., Grewcock v. Yale New Haven Health Services Corp., 293 F. Supp. 3d 272 (D. Conn. 2017) (gender discrimination claims filed under Title VII and the Connecticut Fair Employment Practices Act (CFEPA)).

${ }^{72}$ Specifically, the sample includes cases evaluated per motions to dismiss under FED. R. CIV. P. 12(b)(6), FED. R. CIV. P. 56 and FED. R. CIV. P. 50. The sample also includes cases evaluating a motion to certify a class under FED. R. CIV. P. 23. Cases which raise other evidentiary and procedural issues were not included in the sample or were evaluated only in regards to the parts which addressed other dispositive motions.

${ }^{73}$ See FED. R. CIV. P. 12(b)(6) (a complaint must include a short and plain statement of the claim showing that the pleader is entitled to relief) and FED. R. CIV. P. 56 (summary judgment may only be granted if the movant shows that there is no genuine issue as to any material fact and the movant is entitled to judgment as a matter of law).

${ }^{74}$ See infra p. 20.

${ }^{75} \mathrm{Id}$. (the authors coded case outcomes as "favoring plaintiff" based on any ruling which allowed a plaintiff to proceed past the preliminary motion stage in a gender discrimination claim, including cases where the plaintiff could proceed under state law).
} 
court's ruling did not allow any gender discrimination claim to move forward, the case was coded as "favoring defendant."76

At times, the coding determination was complex. For example, in cases where the procedural issue was based on a motion to dismiss per Rule 12(b)(6), the case was coded as "favoring plaintiff" if the gender discrimination claim challenged in the motion was allowed to proceed past the pleading stage. ${ }^{77}$ As cases at this procedural posture are in the nascent stages of litigation, the "favoring plaintiff" code does not necessarily indicate the ultimate success of the plaintiff's case. ${ }^{78}$ Likewise, a denial of defendant's motion for summary judgment on a gender discrimination claim does not indicate the plaintiff's ultimate success on the claim. ${ }^{79}$ However, the focus of this research was to assess whether a relationship existed between cases which recognized the viability of a gender discrimination claim and the demographics of the judge presiding on the dispositive motion. ${ }^{80}$ A focus on the ultimate outcome of the case would necessarily involve studying the final determination of a fact-finder, judge or jury, which is less likely to generate a written opinion explaining the reasons for the outcome and less likely to relate specifically to the relevant traits of the fact-finder. ${ }^{81}$

\section{B. THE STATISTICAL ANALYSIS AND RESULTS}

The selection procedure described above resulted in a total of 160 cases for subsequent analysis. For each case, data was gathered on the presiding judge's gender, race, age at time of

\footnotetext{
${ }^{76} I d$. (the authors coded case outcomes as "favoring defendant" if all the gender discrimination claims were dismissed at the motion stage, thus foreclosing the plaintiff from litigating the gender discrimination issues in the studied case). 77 See, e.g., Ayala v. Frito-Lay, Inc., 263 F. Supp. 3d 891 (E.D. Cal. 2017).

${ }^{78}$ See, e.g., Yousef v. Fairview Health Services, 63 F. Supp. 3d 969 (D. Minn. 2014), aff'd in part, vac. in part, remanded by $607 \mathrm{Fed}$. App'x 604 ( $8^{\text {th }}$ Cir. 2015).

${ }^{79}$ See, e.g., Perry v. Autozoners, LLC, 954 F. Supp. 2d 599 (W.D. Ky. 2013); Hellmann-Blumberg v. Univ. of the Pacific, No. 2:12-cv-00286 TLN DAD, 2014 WL 1025111 (E.D. Cal. March 17, 2014).

${ }^{80}$ See infra p. 10.

${ }^{81}$ See Kang et al., supra note 30.
} 
decision, and political affiliation (the predictor variables); as well as for whether the presiding judge ruled for the plaintiff or the defendant (the outcome variable). All variables were appropriately coded and entered into the Statistical Program for Social Sciences 25 for further analyses. ${ }^{82}$ There were no missing values, so all cases were included for subsequent analyses to explore the main research question.

Across all the cases, the gender breakdown of the judges was 105 males (65.6\%) and 55 females (34.4\%), and the mean age was 61.38 with a standard deviation 10.00 . The majority of the presiding judges were White/European-American ${ }^{83}$, followed by Black/African-American ${ }^{84}$, Hispanic/Latin-American ${ }^{85}$, and Asian-American ${ }^{86}$. Bill Clinton had appointed the greatest number of these presiding judges ${ }^{87}$, followed by George W. Bush, ${ }^{88}$ Barack Obama, ${ }^{89}$ George H.W. Bush, ${ }^{90}$ Ronald Reagan, ${ }^{91}$ Jimmy Carter, ${ }^{92}$ and Gerald Ford. ${ }^{93}$ Of the 160 cases, 70 (43.75\%) of the presiding judges ruled for the plaintiff and 90 (56.25\%) ruled for the defendant.

This study's fundamental inquiry asks whether the presiding judges' final dispositions in Title VII gender discrimination cases can be predicted on the basis of their gender, race, age, and political affiliation. Multiple linear regression is typically the most appropriate statistical method used to answer such a research question, namely, whether a collection of variables can predict a

\footnotetext{
${ }^{82}$ SPSS is the acronym for the Statistical Package for the Social Sciences, one of the most popular statistical programs used in social science research. SPSS is a product of IBM Corporation. IBM SPSS Statistics, IBM, https://www.ibm.com/products/spss-statistics (last visited Feb. 27, 2019).

${ }^{83} \mathrm{n}=125$, or $78.12 \%$

${ }^{84} \mathrm{n}=21$, or $13.13 \%$

${ }^{85} \mathrm{n}=8$, or $5.0 \%$

${ }^{86} \mathrm{n}=6$, or $3.75 \%$

${ }^{87} \mathrm{n}=46$ or $28.75 \%$

${ }^{88} \mathrm{n}=45$, or $28.13 \%$

${ }^{89} \mathrm{n}=39$, or $24.38 \%$

${ }^{90} \mathrm{n}=14$, or $8.75 \%$

${ }^{91} \mathrm{n}=11$, or $6.88 \%$

${ }^{92} \mathrm{n}=2$, or $1.25 \%$

${ }^{93} \mathrm{n}=1$, or $.63 \%$
} 
single outcome variable. ${ }^{94}$ The current study's outcome variable, disposition, is categorical and binary in nature. ${ }^{95}$ Binary logistic regression is a specific form of multiple regression that is employed when assessing the predictive influence of a set of variables on a single binary outcome, and as such was employed here. ${ }^{96}$ Peng, Lee, and Ingersoll provide a general abbreviated summary of logistic regression analysis and results reporting ${ }^{97}$, and Tabachnick and Fidell ${ }^{98}$ provide a more detailed and sophisticated overview of the mathematics underlying the procedure.

Because of smaller number of cases in certain categories of race ${ }^{99}$ and political affiliation ${ }^{100}$, these variables were collapsed to avoid violating the important statistical criterion related to minimum 'expected values' ${ }^{101}$ and to ensure further analyses would produce robust and stable results. Collapsing across variables is the recommended convention so long as one can rationalize how it is done. ${ }^{102}$ As such, race was recoded into European-American/White ${ }^{103}$ and

\footnotetext{
${ }^{94}$ For a comprehensive review of multiple regression statistical applications and procedures, see JACOB COHEN, Patricia Cohen, Stephen G. West, \& LeOna S. Aiken, ApPlied MultiPle Regression/Correlation Analysis FOR THE BEHAVIORAL SCIENCES (3d ed. 2002).

${ }^{95}$ E.g., a binary outcome has only two possible values, here judgment favoring either the plaintiff or the defendant.

${ }^{96}$ E.g., binary logistic regression is the appropriate statistical technique when one is looking at how a group of variables (here, judges' gender, race, age, and political affiliation) together predicts an outcome that only has two mutually exclusive possible values (here, ruling for plaintiff or defendant). For greater explanation of binary logistic regression and its applications and procedures, see BARBARA G. TABACHNICK, \& LINDA S. FIDELL, USING MulTivariate Statistics (5th ed. 2007).

${ }^{97}$ Chao-Ying Joanne Peng, Kuk Lida Lee \& Gary M. Ingersoll, An Introduction to Logistic Regression Analysis and Reporting, 96 J. OF EDUC. RES. 3 (2002).

${ }^{98}$ See TABACHNICK \& FIDELL, supra note 96.

${ }^{99}$ E.g., Asian-American.

${ }^{100}$ E.g., Ford appointees.

${ }^{101}$ Expected values are a direct function of the number of cases in each level of all categorical variables. Because of the large discrepancy of number of cases in certain variables (e.g., 135 White/European-American judges compared to only 6 Asian-American judges), this violation was violated. It is not uncommon for this to occur, and when it does, collapsing across variable categories is an appropriate remedy. See TABACHNICK \& FIDELL, supra note 96.

102 See TABACHNICK \& FIDELL, supra note 96.

${ }^{103} \mathrm{n}=125$, or $78.12 \%$.
} 
non-European-American/non-white ${ }^{104} ;$ and political affiliation into Republican ${ }^{105}$ and Democrat. $^{106}$

The output reported here of the binary logistic regression follows the recommendations of Peng et al. ${ }^{107}$ According to Peng et al., the first analysis is an overall assessment of the full model that includes all predictor variables to examine their effect, as a set, on the outcome variable. ${ }^{108}$ All of the predictor variables were simultaneously entered into the regression equation as a set ${ }^{109}$ and the judge's disposition entered as the binary outcome variable. Results indicated that this omnibus test of model coefficients was not statistically significant ${ }^{110}$ at the conventional $p<.05$ criterion level. ${ }^{111}$ Stated another way, dispositional outcome based on the set of predictors was predicted no better by the equation than by random chance alone. ${ }^{112}$ In some research studies, a more liberal $p$-value of $.10^{113}$ is employed as the criterion when the consequences of incorrectly determining a model's predictive ability as 'better than chance' are less severe. While such a case

\footnotetext{
${ }^{104} \mathrm{n}=35$, or $21.78 \%$.

${ }^{105} \mathrm{n}=71,44.38 \%$.

${ }^{106} \mathrm{n}=89$, or $55.63 \%$.

107 See Peng et al., supra note 97.

108 See id. at 5.
}

${ }^{109}$ Multiple options exist for how predictors are entered into a regression equation. Entering predictors simultaneously (i.e., all together at once) as done here is also referred to as the 'direct entry method' and is appropriate when a researcher is not making an a priori prediction as to which particular predictor(s) will have the strongest relationship with the outcome. See TABACHNICK \& FIDELL, supra note 96.

110 The statistical test performed was a Chi-square analysis with the following notation: $\left.X^{2}(4, N=160)=7.09, p=.13\right)$. The value, 7.09, failed to achieve a threshold that would indicate that the predictors did explain the outcome at a statistically significant level.

111 The standard criterion level for statistical significance is $p<.05$. If an analysis produces a $p$-value, or probability value, that is equal to or greater than .05 , the result is deemed not statistically significant; significance is only achieved when a $p$-value is less than .05 . In this analysis, $p=.13$, which is greater than .05 thus deeming it not statistically significant.

${ }^{112} I d$.

${ }^{113}$ Researchers determine the p-value they will use as a criterion for statistical significance prior to analyses. The convention is $p<.05$. Depending on the nature of the study, researchers can make it easier to attain statistical significance by increasing the $p$-value to .10. It is not typical to use a p-value of .10 in social science research, but permissible in early exploratory research. However, statistical significance at the .10 level is not as convincing as it is at the .05 level and is rarely used to make definitive conclusions about a finding. 
could be made for the current study, the observed $p=.13$ still exceeds that criterion. ${ }^{114}$ In essence, the overall equation for the model generated suggests that, even though there might be some subtle relationships between the predictors and dispositional outcome, they are at best tenuous and statistically nonsignificant. ${ }^{115}$

Peng et al. recommend next examining the overall goodness of fit for the generated model. ${ }^{116}$ Nagelkerke's R-Square, which is one of the most often-used indicators ${ }^{117}$ of the relative magnitude of the model's predictive ability, had a value of .06. ${ }^{118}$ As Nagelkerke's R-Square can range from 0 to 1.0 , a value of .06 indicates that the extent to which the set of variables are predicting the dispositional outcome is fairly small. ${ }^{119}$

Although it is informative, Peng et al. suggest using Nagelkerke's R-Square value as a supplementary indicator to be complemented by the other analyses. ${ }^{120}$ Peng et al. cite Hosmer and Lemeshow who state that among the various statistical outputs generated by binary logistic regression, "...the classification table is the most appropriate when classification is a stated goal of the analysis." 121 As the current study's focus is on classification of judge's dispositions, the

\footnotetext{
${ }^{114}$ As the p-value here was .13 , it is 'closer' to the .10 criterion than the .05 one; i.e., it would have been 'closer' to being statistically significant. However, even still, the result would not be significant if a .10 criterion were used.

${ }^{115}$ Statistical significance is a function of multiple factors (e.g., sample size, variability, random error and chance) as well as the observed patterns in the data. As a result, there might be patterns in the data that suggest a relationship exists but it may still fail to achieve statistical significance because these other factors. For example, if the same patterns observed in this data were present in a sample of 10,000 instead of 160, the result might be statistically significant. However, statistical significance can ultimately only be determined for a given result based on these factors as they exist in the study as it was actually performed. See WILLIAM L. HAYS, STATISTICS (5th ed. 1994).

${ }^{116}$ See Peng et al., supra note 97 at 6.

${ }^{117}$ See id.; See TABACHNICK \& FIDELL, supra note 96.

${ }^{118}$ In ordinary least squares multiple regression, the commonly reported R-Square statistic refers to the amount of variance in the outcome that is explained by predictor(s). Although conceptually different, Nagelkerke's R-Square is a variation of this from a 'fit' perspective.

${ }^{119}$ As with R-Square, a Nagelkerke's R-Square of 1.0 would indicate that the set of variables perfectly predicted an outcome; a value of 0 would indicate that the set of variables had absolutely no predictive ability at all. See Peng et al., supra note 97.

${ }^{120}$ See Peng et al., supra note 97 at 6.

${ }^{121} I d$. at 8 (quoting DAVID W. HoSMER, \& STANLEY LEMESHOW, APPLIED LOGISTIC REGRESSION (2d ed. 2000).
} 
classification table was examined. ${ }^{122}$ The classification table indicated that the best-fitting model of the predictors-outcome relationship yielded a rate of $61.90 \%$ correctly predicted cases, which when compared to the $56.35 \%$ in the null model ${ }^{123}$ reflects a $4.55 \%$ improvement in accuracy. While not a tremendous increase, this increase suggests that the set of predictors ${ }^{124}$ led to at least a marginal improvement in predicting a disposition favoring the plaintiff or defendant.

According to Peng et al., the next step in interpreting binary logistic regression analyses is an examination of each individual predictor variable's influence on the outcome. ${ }^{125}$ As can be seen in Table 1, the presiding judge's gender, race ${ }^{126}$, and their political affiliations' political party ${ }^{127}$ had no individual statistically significant effects on disposition at the $p<.05$ or even $p<.10$ criteria. Stated another way, none of these variables reliability predicted the disposition outcome.

\section{Table 1}

\begin{tabular}{|lcccccc|}
\hline \multicolumn{7}{|l|}{ Binary Logistic Regression Results: Outcome=Disposition } \\
\hline & B & S.E. & Wald's $X^{2}$ & df & Sig. & Exp(B) \\
\hline Gender & -.545 & .358 & 2.317 & 1 & .128 & .580 \\
Race $^{128}$ & .348 & .407 & .734 & 1 & .392 & 1.442 \\
Age at Decision $^{130}$ & -.035 & .018 & 3.906 & 1 & $.048^{129}$ & .966 \\
Political affiliation $^{130}$ & .339 & .345 & .964 & 1 & .326 & 1.403 \\
Constant & 1.601 & 1.155 & 1.922 & 1 & .166 & 4.960 \\
\hline
\end{tabular}

\footnotetext{
122 The classification table is simply another means to assess the overall model fit in a binary logistic procedure. See Peng et al., supra note 97; See TABACHNICK \& FIDELL, supra note 96.

${ }^{123}$ E.g., percentage of observed rulings for the defendant with no influence of predictor variables.

${ }^{124}$ E.g., presiding judges' age, gender, race (binary), and political affiliations' political party.

125 See Peng et al., supra note 97 at 8.

${ }^{126}$ E.g., European-American/White or non-European-American/non-White.

${ }^{127}$ E.g., Democrat or Republican.

${ }^{128}$ Race is collapsed and coded as European-American/White or non-European-American/ non-White.

${ }^{129} p<.05$, thus this is a statistically significant finding.

${ }^{130}$ Political affiliation is collapsed and coded as Republican or Democrat.
} 
Based on the Wald criterion ${ }^{131}$, judge's age at the time of disposition was the only predictor on its own that reliably predicted whether a ruling favored the defendant or plaintiff. ${ }^{132}$ More specifically, presiding judges who were older at the time of disposition were more likely to rule in the defendant's favor than the plaintiff's. The odds ratio B(exp) for age was .966 , which reflects the change in the likelihood of favoring the plaintiff or defendant on the basis of a one-unit change in age (i.e., year) ${ }^{133}$ Stated another way, for every year older a judge is, the odds of correctly predicting their decision for the defendant increases by approximately $3.40 \%$. Overall, these results indicate that, of the predictor variables, only the judge's age at time of decision was a statistically significant predictor of their disposition.

Binary logistic regression is a multivariate procedure that analyzes multiple variables in the context of each other. ${ }^{134}$ As a result, at times a relationship between a predictor and outcome can be influenced by the effects of other variables. ${ }^{135}$ Since the binary logistic regression results found no statistically significant bivariate relationships ${ }^{136}$ between disposition and gender, race (binary), and political affiliation (binary); a series of Chi-square analyses were conducted to examine the isolated bivariate relationships. ${ }^{137}$ Results indicated that there were no statistically significant differences in disposition, even at the liberal $p<.10$ level, between male and female

\footnotetext{
131 The Wald test is the standard statistical test used to determine whether each individual variable in a binary logistic regression equation statistically significantly predicts the outcome. See Peng et al., supra note 97; See TABACHNICK \& FIDELL, supra note 96.

132 The Wald test uses a Chi-Square analysis to test the statistical significance of each predictor. The notation for the statistical test for judge's age at time of disposition is $X^{2}(1, N=160)=3.91, p<.05$.

${ }^{133}$ The odds ratio, or $\mathrm{B}(\exp )$ is a value that indicates the degree to which the odds of a participant being classified on the binary outcome (i.e., ruling for plaintiff or defendant) increase or decrease as a function of a given predictor. See Peng et al., supra note 97; See TABACHNICK \& FIDELL, supra note 96.

134 See TABACHNICK \& FIDELL, supra note 96.

${ }^{135} \mathrm{Id}$.

${ }^{136}$ A bivariate relationship is the relationship between two variables.

${ }^{137}$ Chi-square is the appropriate statistical procedure to use when examining the relationship between two categorical variables (i.e., the values of each variable have no quantitative properties).
} 
judges $^{138}$, between European-American/White and non-European-American/non-White judges ${ }^{139}$,or between judges appointed by Democratic and Republican presidents. ${ }^{140}$

As judge's age at time of decision was found to be a significant predictor of disposition in the binary logistic regression, a series of independent samples t-tests was conducted for purely exploratory purposes to see if age differences existed across the other predictor variables. ${ }^{141}$ Significant differences in age were observed at the $p<.05$ level between male ${ }^{142}$ and female ${ }^{143}$ judges $^{144}$; and between judges who were appointed by Republican ${ }^{145}$ and Democratic ${ }^{146}$ presidents. $^{147}$ The age difference between European-American/White ${ }^{148}$ and non-EuropeanAmerican/non-White ${ }^{149}$ was statistically significant at the $p<.10$ level. ${ }^{150}$

These analyses, although informative, cannot fully capture potential racial differences within the non-European-American/non-White category. For example, although both were included in the Republican category of political affiliation, Ronald Reagan appointed almost exclusively male (10, compared to 1 female) judges whereas George H.W. Bush was more gender balanced in appointing 8 males and 6 females. ${ }^{151}$ Similarly, although both were included in non-

\footnotetext{
${ }^{138} X^{2}(1, N=160)=1.06, p=.33$.

${ }^{139} X^{2}(1, N=160)=.56, p=.61$.

${ }^{140} X^{2}(1, N=160)=.97, p=.33$.

${ }^{141}$ An independent samples t-test is the statistical procedure one uses when comparing two groups on an intervallevel scale (i.e., the scale has a common metric). See HAYS, supra note 115.

${ }^{142} M=62.75, S D=10.54$.

${ }^{143} M=58.76, S D=8.39$.

${ }^{144} t(158)=2.43, p=.02$.

${ }^{145} M=63.77, S=10.64$.

${ }^{146} M=59.47, S D=9.08$.

${ }^{147} t(158)=2.76, p=.01$.

${ }^{148} M=62.18, S D=9.48$.

${ }^{149} M=58.54, S D=11.40$.

${ }^{150} t(158)=1.92, p=.07$ (the original race and political affiliation categories were collapsed to avoid violation of assumptions related to minimum numbers of case observations).

${ }^{151}$ See e.g., Murray v. Town of Stratford, 996 F. Supp. 90 (D. Conn. 2014) (decided by Judge Joan Glazer Margolis, Reagan appointee); Noel v. Shell Oil Company, 261 F. Supp. 3d 752 (S.D. Tex. 2017) (decided by Judge Nancy K. Johnson, George H.W. Bush appointee).
} 
European-American/non-White category of race and the same sample size, Asian-American judges were 5 times more likely to be female whereas Hispanic judges were three times more likely to be male. ${ }^{152}$

\section{INTERPRETATIONS OF FINDINGS}

The authors embarked on this research without a predetermined theory of what relationships between decisions and demographics would prove meaningful. The research attempted to measure statistically significant relationships between the identified demographics and the plaintiff/defendant favoring results in the selected Title VII cases, and despite some complexities related to mixed demographics, e.g. female and non-white, the research accurately analyzes the relevant subject. ${ }^{153}$ Of course, the relationship between case outcomes and gender were of specific interest to the authors. As is noted above, the analysis of the sample did not find a statistically significant relationship between the case outcomes and race, gender, or political affiliation. ${ }^{154}$ Thus, based on this study, we can say that non-white judges did not favor either plaintiff or defendant positions in ruling on dispositive motions under Rules $12(\mathrm{~b})(6)$ or $56 .{ }^{155} \mathrm{We}$ can also say that male judges do not rule in a manner that shows a preference for defendants in gender-based discrimination cases brought under Title VII, at least not in the early stages of litigation, and that female judges do not favor plaintiffs in gender-based discrimination cases. ${ }^{156}$

\footnotetext{
${ }^{152}$ See e.g., Hubbell v. World Kitchen, LLC, 688 F. Supp. 2d 401 (W.D.P.A. 2010) (decided by Judge Joy Flowers Conti); Powell v. Lockhart, 629 F. Supp. 2 d 23 (D.D.C. 2009) (decided by Judge Ricardo M. Urbina) Although there may be other general similarities within and differences between each binary category to rationalize how cases are assigned, inadequate sample sizes precluded statistical inference testing without collapsing these variables as was done.

${ }^{153}$ Supra p. 21.

${ }^{154}$ Supra p. 20.

${ }^{155}$ Supra p. 20; see also FED. R. CIV. P. 12(b)(6) and FED. R. CIV. P. 56.

${ }^{156}$ Supra p. 20.
} 
It is tempting to classify these results as disappointing until you remove yourself from preconceptions on gender-bias and evaluate the research results from an institutional point of view. ${ }^{157}$ This research is an examination of judging and of the judiciary, rather than an examination of the likelihood of success of a female litigant in front of a female judge. Indeed, if the research demonstrated a statistically significant relationship between the plaintiff's favorable outcome and the presence of a female judge, female plaintiffs in gender-based discrimination cases would be in a far worse situation as the majority of the federal district court judiciary is male. ${ }^{158}$ In contrast, the research serves to reassure litigants that the judge's race, gender, and political affiliation, ${ }^{159}$ will not impact the judge's ruling on the early dispositive motions that often determine the success of the plaintiff's case. However, the age of the presiding judge may impact the litigant's success.

\section{A. Findings Regarding AgE}

The research found a statistically significant relationship between the presiding judge's age and the favorable outcome to either plaintiff or defendant. ${ }^{160}$ The research supports the supposition that a female litigant in a gender-based discrimination case is more likely to be successful at the

\footnotetext{
${ }^{157}$ The authors note here the irony that occurs in this type of research when you approach the results from the bias of anticipating male judges to favor male defendants and female judges to favor female plaintiffs. This expectation contains its own implicit gender bias.

${ }^{158}$ Demography of Article III Judges, 1789-2017, FED. JUDICIAL CTR., https://www.fjc.gov/history/exhibits/graphsand-maps/gender (last visited Dec. 27, 2019) (in 2017, female judges constitute $34 \%$ of federal district court judges and male judges constituted $66 \%$; the number of women appointed to the federal bench has increased substantially since 1970 as recent Presidents have appointed more women to the bench).

${ }^{159}$ Supra p. 20, Table 1.

${ }^{160}$ Supra p. 20, Table 1.
} 
dispositive motion stage in front of a younger judge, regardless of that judge's race, gender or political affiliation. ${ }^{161}$

The sample included 55 decisions by female judges. ${ }^{162}$ Within that group, the female judges ranged in age from $42^{163}$ to $75^{164}$, with three female judges exceeding 70 years of age at the time of the decision. ${ }^{165}$ The remaining 105 decisions included in the sample were authored by male judges ranging in age from $43^{166}$ to $93^{167}$ with 22 male judges exceeding 70 years of age at the time of the decision and 3 male judges exceeding 90 years of age at the time of the decision. ${ }^{168}$ The average age of all the presiding judges at the time of the decision is 61: the average age of male presiding judges at the time of the decision is 63 and the average age of female presiding judges at the time of the decision is 58 .

The findings on age raise several complicated issues. First, age may encompass other factors, such as time in the judiciary. ${ }^{169}$ A judge serving for a longer period may have more experience with Title VII cases and a broader frame of reference. This broader frame may indicate

\footnotetext{
${ }^{161}$ Supra p. 20, Table 1; see also Demography of Article III Judges, 1789-2017, FeD. JudiCiAL CTR., https://www.fjc.gov/history/exhibits/graphs-and-maps/gender (last visited Dec. 27, 2019) (federal judges over 70 years old are predominantly white and male thus gender and racial diversity decline in older judges).

${ }^{162}$ Some judges in the sample authored more than one opinion in the sample, e.g. Judge Margaret Brodie, but the age used in the sample was the judge's age at the time of the particular decision, thus some judges are in the research sample more than once with different ages based on the date of the decision. See Ellis v. Century 21 Dep't Stores, 975 F. Supp. 2d 244 (E.D.N.Y. 2013); Batchelor v. City of New York, 12 F. Supp. 3d 458 (E.D.N.Y. 2014); Setelius v. Nat'l Grid Elec. Servs., LLC, No. 11-CV-5528 (MKB) 2014 WL 4773975 (E.D.N.Y. Sept. 24, 2014); Campbell v. N.Y.C. Transit Auth., 93 F. Supp. 3d 148 (E.D.N.Y. 2015).

${ }^{163}$ See Cook v. Triple Transcript, Inc., 928 F. Supp. 2d 1061 (E.D. Ark. 2013) (decided by Judge Kristine Baker).

${ }^{164}$ See Murray v. Town of Stafford, 996 F. Supp. 90 (D. Conn. 2014) (decided by Judge Joan Glazer Margolis).

${ }^{165}$ See Peralta v. Roros, 940, 72 F. Supp. 3d 385 (E.D.N.Y. 2014) (decided by Judge Nina Gershon); Murray, 996 F. Supp. at 90 (decided by Judge Joan Glazer Margolis); Barnett v. PA Consulting Group, Inc., 818 F. Supp. 2d 159 (D.D.C. 2011) (decided by Judge Barbara Jacobs Rothstein).

${ }^{166}$ See Morris v. David Lerner Assocs., 680 F. Supp. 2d 430 (E.D.N.Y. 2010) (decided by Judge Joseph Bianco).

${ }^{167}$ See Petty v. City of Topeka, No. 12-4080-RDR, 2013 WL 5774847 (D. Kan. Oct. 25, 2013) (Judge Richard D. Rogers).

${ }^{168}$ See Zito v. Fried, Frank, Harris, Shriver \& Jacobson, LLP, 869 F. supp. 2 d 378 (S.D.N.Y. 2012) (decided by Judge Robert W. Sweet); Conforti v. Sunbelt Rentals, Inc., 201 F. Supp. 3d 278 (E.D.N.Y. 2016) (decided by Judge Arthur D. Splatt); Petty, 2013 WL 5774847 (decided by Judge Richard D. Rogers).

${ }^{169}$ See Demography of Article III Judges, 1789-2017, FED. JUDICIAL CTR. https://www.fjc.gov/history/exhibits/graphsand-maps/gender (last visited Feb. 26, 2019).
} 
a greater understanding of the plaintiff's claim or it may indicate less familiarity with common workplace issues. ${ }^{170}$ Age may also indicate less familiarity with cultural changes, including changes in the workplace and in society involving the advancement of women. ${ }^{171}$ As the law of Title VII demonstrates, what is acceptable behavior in the workplace has changed drastically over the past forty years with the evolution of actionable sexual harassment and gender discrimination cases. ${ }^{172}$ Depending on the cases filed in a particular judicial district or the overall workload of a given federal district court, the presiding judge may or may not be experienced in handling Title VII cases. ${ }^{173}$ However, overall increases in litigation under Title VII suggest that all federal judges appointed after 1970 would be more likely to have experience with Title VII gender discrimination cases, even in districts with less filings overall. ${ }^{174}$ Thus, younger judges more recently appointed to the bench may be in a better position to assess a Title VII gender-discrimination case due to the prevalence of gender discrimination claims in federal court, and also due to personal experience in more gender diverse workplaces. ${ }^{175}$ The impact of more recent workplace experience and other

\footnotetext{
${ }^{170}$ See One judge in the research sample was appointed by President Gerald Ford. Petty, 2013 WL 5774847; several others were appointed by President Ronald Reagan and President George H.W. Bush. See e.g., Graber v. Mad Brewer, Inc., 773 F. Supp. 2d 765 (N.D. Ind. 2011) (Judge James T. Moody was appointed by President Reagan in 1981); See e.g., Noel v. Shell Oil Co., 261 F. Supp. 3d 752 (S.D. Tex. 2017) (Judge Nancy K. Johnson was appointed by President Bush in 1990).

${ }^{171}$ See Andrea L. Miller, Expertise Fails to Attenuate Gendered Biases in Judicial Decision-Making, Soc. PsYCHOL. \& PERSONALITY SCI. 1 (April 2, 2018), https://journals.sagepub.com/doi/pdf/10.1177/1948550617741181.

172 See generally Gillian Thomas, Because of Sex: One Law, Ten Cases and Fifty Years that Changed AMERICAN Women's LIVES AT WORK 240 (2016); see also Petty, 2013 WL 5774847 (Judge Richard Rogers was appointed by President Ford in 1975, 38 years before the decision included in the research sample).

${ }^{173}$ Federal Judicial Caseload Statistics 2018, U.S. COURTS, https://www.uscourts.gov/statistics-reports/federaljudicial-caseload-statistics-2018 (last visited Dec. 27, 2019). The authors note that judges on senior status (which are included in the sample, e.g. Judge Raymond L. Acosta, are even less likely to have experience with bias-based gender discrimination cases.

${ }^{174}$ See Id.; see also THOMAS, supra note 172.

175 See generally JoAn C. Williams et. AL, ABA COMm'N ON Women In the Profession, You CAN't Change What You Can't SeE: Interrupting Racial \& Gender Bias in the Legal Profession (2018), https:/www.americanbar.org/content/dam/aba/administrative/women/Updated\%20Bias\%20Interrupters.pdf. $\quad$ By comparison, the recent controversy over Justice Brett Cavanaugh highlights how youth and more recent experience can create conflicting suggestions regarding bias. In Justice Cavanaugh's case, his history suggested that his behavior in high school and college indicated bias as it referenced a past era of male-dominated culture. However, the competing suggestion was that those experiences, combined with his experience in the workplace and on the bench,
} 
cross-cultural experiences would be present in both male and female judges, perhaps indicating why age is a more important comparative factor than gender. ${ }^{176}$

The theory of Third Generation Discrimination suggests that implicit bias in the judiciary can work to perpetuate workplace bias by using neutral procedural devices, such as the Rule 12(b)(6) and Rule 56 motions, to dismiss Title VII bias-based gender discrimination cases. ${ }^{177}$ The relevant finding here on age supports this theory. If the presiding federal judge lacks certain experiences that tend to reduce gender bias, such as work experience in a gender diverse workplace or experiences with opposite gender colleagues in professional and cultural environments without a power differential, the judge may put his or her own bias into the decision making process. ${ }^{178}$ The age of the judge, more than the judge's gender alone, may be an indicator of the judge's relevant experience with cross-gender interaction and resulting implicit biases. ${ }^{179}$ This lack of experience leads to the same result that occurs in the workplace - the facially neutral decision favors the male-dominant group, inuring to the long-term benefit of the male-dominated majority. ${ }^{180}$ The presiding judge measures the next bias-based gender discrimination case against the last and the self-perpetuating cycle of implicit bias continues.

served to make him more responsive to bias-based gender discrimination.

176 See supra p. 25.

177 See Dunham, supra note 7.

${ }^{178}$ See EnHANCING JustiCE: ReduCING Bias 87-131 (Sarah E. Redfield ed. 2018); see also Kang et al, supra note 30, at 1160 ("Decades of social psychological research demonstrate that our impressions are driven by the interplay between categorical (general to the category) and individuating (specific to the member of the category) information. For example, to come to an impression about a Latina plaintiff, we reconcile general schemas for Latina workers with individualized data about the specific plaintiff. When we lack sufficient individuating information-which is largely the state of affairs at the motion to dismiss stage — we have no choice but to rely more heavily on our schemas.").

${ }^{179}$ See Shari V.N. Hodgson \& Burt Pryor, Sex Discrimination in the Courtroom: Attorney's Gender and Credibility, 71 WOMEN LAW. J. 7 (1985) (research which studied the relationship between attorney's gender and perceived credibility showed that it was the women participants who rated female attorneys significantly lower on six of the twelve credibility scales); see also Anne Weklsh McNulty, Don't Underestimate the Power of Women Supporting Each Other at Work, HARV. BuS. REV., (Sept. 3, 2018), https://hbr.org/2018/09/dont-underestimate-the-power-ofwomen-supporting-each-other-at-work ("[S] enior level women who champion younger women even today are more likely to get negative performance reviews.").

${ }^{180}$ See supra Second Generation Discrimination Continuum p. 5. 
The import of the finding that age correlates to outcome is that aging is an ongoing process. Despite some high profile exceptions, research indicates that Generation $\mathrm{X}$ and Millennials are more diverse, value diversity and operate comfortably in less structured and segregated environments. ${ }^{181}$ Federal courts currently house judges from these generational groups and those numbers will only increase as the pool of appropriate candidates from post Baby Boom generations grows. ${ }^{182}$ If what we currently know and hypothesize about the Millennial and Generation $\mathrm{X}$ populations holds true, we can expect the judiciary to not only be more diverse in gender, race, and viewpoint, but also to be able to approach gender-based discrimination cases with a greater self-awareness of the impact of bias.

It is tempting to cajole the finding that age correlates to defendant-favorable rulings in Title VII gender-based discrimination cases into an indictment of the appointed judiciary and the lifetime status of federal judges under Article III. ${ }^{183}$ However, this study only examines judicial decisions in a certain type of gender-discrimination case, thus is too narrow to support theories for broader institutional changes. In fact, the study's findings on race, gender and political affiliation suggest the current appointment system results in some measure of fairness. ${ }^{184}$

\footnotetext{
${ }^{181}$ Kristen Bialik \& Richard Fry, Millennial Life: How Young Adulthood Compares with Prior Generations, Pew ReS. CTR. (Feb. 14, 2019), http://www.pewsocialtrends.org/essay/millennial-life-how-young-adulthood-today-compareswith-prior-generations/.

${ }^{182}$ Id. Baby Boomers are those persons between 55-73 in 2019, Generation X are those persons between 39-54 in 2019; Millennials are those persons between 22-38 in 2019; and Generation $Z$ are those persons age 22 and under in 2019. All the judges in the research sample are over 39 so the sample does not include any Millennial or Generation $\mathrm{Z}$ judges. The average age of the judges in the sample is 61 making the Baby Boomer Generation the most represented in the sample. Supra p.21.

${ }^{183}$ See U.S. CONST. art. III, § 1 ("The judicial power of the United States, shall be vested in one Supreme Court, and in such inferior courts as the Congress may from time to time ordain and establish. The judges, both supreme and inferior courts, shall hold their offices during good behavior, and shall, at stated times, receive for their services, a compensation, which shall not be diminished during their continuance in office.").

${ }^{184}$ Supra pp. 24-26.
} 


\section{B. Findings Regarding Gender, RACE AND Political AfFILIATION}

The study did not find a statistically significant relationship between the outcome determination in bias-based gender discrimination cases under Title VII and the presiding judge's race, gender, or political party affiliation. ${ }^{185}$ These findings are important for two main reasons. First, legal culture on both the state and federal level has adopted the practice of forum shopping as part of the routine litigation strategy. ${ }^{186}$ Indeed, some forms of forum shopping are healthy strategic practices, such as when forum shopping intersects with choice of law or when venue and subject matter jurisdiction rules allow for choices between multiple available forums. ${ }^{187}$ However, forum shopping often devolves into judge-shopping which involves its own system of bias-based decision making. ${ }^{188}$ A lawyer may attempt to engineer placement of a race-based discrimination case before a non-white judge. Or, as studied here, a female litigant may be advised her genderbased discrimination case is more likely to be successful before a female judge. These preconceptions flow from a bias that is not only shown to be incorrect but also serves to drive the forum decision in a manner that may not lead to the best outcome for the prosecuting party. ${ }^{189}$

As in many examinations of bias, assumptions on race and gender layer onto themselves, obfuscating our acceptance of independent assessment and thought. This is particularly important in matters of judicial decision-making as the courts serve as society's interpreters of justice. If a

\footnotetext{
185 Supra p. 20.

186 See Christopher A. Whytock, The Evolving Forum Shopping System, 96 CORNELL L. REV. 481, 487 (2010-2011).

${ }^{187} \mathrm{Id}$. at $485-490$.

188 See Jenkins v. Bellsouth Corp., No. Civ.A.CV-02-1057-S, 2002 WL 32818728 (N.D. Ala. Sept. 13, 2002) ("Some states expressly permit judge-shopping, allowing the parties peremptory challenges to the judge. The possibility of permitting this maneuver in federal courts has been broached to the Congress, but never adopted. In federal court, the parties clearly have no right to a 'judge of their choice."') (quoting McCuin v. Texas Power \& Light Co., 714 F.2d 1255 (5 $5^{\text {th }}$ Cir. 1983).

189 Supra pp.; see also Erik Voeten, Gender and Judging: Evidence from the European Court of Human Rights (January 25, 2019), https://ssrn.com/abstract=3322607 or http://dx.doi.org/10.2139/ssrn.3322607 (recent study examining whether female litigants alleging discrimination in the European Courts of Human Rights fare better when before a female judge).
} 
female litigant believes she cannot have fair treatment before a male judge, thus must shop her case to a female judge, eschewing other factors of forum choice, she is predisposed to believe that the judicial system also discriminates against her due to her status as a female. The success of her case then becomes a referendum on what judge presides rather than what facts and law control.

Secondly, any study of the judiciary is an institutional study. The best possible result of a study examining bias within the judiciary would be to find that judges, for the most part, do not employ personal biases when evaluating individual cases. In the federal system, where federal district court judges are appointed for a lifetime, findings of judicial bias implicate hundreds of cases as the judge will remain on the bench until death or retirement. ${ }^{190}$ When a federal judge evaluates a discrimination case based on his or her own biases, the course of justice is perverted and the institution is harmed. Although this research is insufficient to assess the functioning and non-functioning biases of the entire federal judiciary, it does suggest that judges, despite race, gender, and political demographics, assess cases based on the arguments before the court rather than on preconceptions about gender, possibly even in bias-based discrimination cases.

\section{CONCLUSION}

Workplace discrimination is not a relic of past times. In fact, bias-based gender discrimination in the workplace continues to thrive as women and men navigate cross-gender contexts in male dominated industries and professions. The question remains whether the courts can serve as fair tribunals to those claiming workplace discrimination. Many factors implicate the fairness of any given litigation, however the study reported here does not support a statement that male federal district court judges are more likely to rule against female plaintiffs in gender

\footnotetext{
${ }^{190}$ U.S. CONST. art. III, § 1; see also Patricia W. Hatamyar Moore, The Civil Caseload of the Federal District Courts, 2015 U. ILL. L. REV. 1177, 1197-98.
} 
discrimination litigation or that female judges are more likely to rule in favor of female plaintiffs. The study does suggest a female plaintiff should be wary of older judges, male or female, as those judges may be less able to understand the relevant theory of gender discrimination, especially when the case is premised on theories of implicit bias-based gender discrimination. As human beings, we are all subject to our biases, conscious and unconscious. But the breadth of human experience can work to ameliorate those biases. As we see increases in the appointment of younger, more diverse judges to the federal court bench, we have reason to be optimistic that those new jurists will bring different types of experiences to their decision-making.

\section{$* * *$}

